\title{
Which Groups Have a Greater Risk of Poverty in Spain?
}

\author{
MARIA CARMEN SÁNCHEZ-SELLERO* \\ BEATRIZ GARCIA-CARRO
}

Faculty of Economics and Business Administration

Department of Applied Economics

University of A Coruña

Coruña, Spain

\author{
Original scientific paper \\ UDK: 364.2(460) \\ doi: $10.3935 /$ rsp.v27i1.1572 \\ Received: July 2018
}

The economic crisis present in Spain since the year 2008 has come accompanied by increases in inequality and in the rates of poverty. The objective of this paper is to determine the most vulnerable social groups in terms of poverty in Spain. The empirical analysis uses the information of the Survey of Living Conditions from 2015, in order to explain poverty catalogued as severe poverty, moderate poverty and without risk of poverty for persons older than 16 years; the explanatory variables are of socio-demographic and labour types, and they represent different groups of the Spanish population. The study applies an ordinal logistic regression model to the data of the Survey of Living Conditions, which will allow us to estimate the probabilities that an over-16 individual is in a situation of moderate poverty, severe poverty, or with no risk of poverty for the different categories analysed. There are a few differences in poverty depending on gender; the categories most affected by the moderate and/or severe poverty are separated and divorced persons, foreigners not from the European Union, persons with low training levels, and those with a temporary contract. We must accept that in the situations of difficulty, there are some groups that, due to their economic conditions, are at a disadvantage to face adverse situations.

Key words: equivalent income, labour, logit, poverty rates, socio-demographic characteristics, thresholds.

JEL CLASSIFICATION: I32, I39, O15, C25.

\section{INTRODUCTION}

Poverty is a phenomenon of great interest and concern at both institutional and social levels (García-Carro and Sánchez-Sellero, 2019). The economic crisis prevailing in all countries in 2008 and thereafter has generated abundant literature on the subject of poverty and social exclusion. Actually, quite unambiguous evidence about the effect of recent economic crisis on inequality and poverty across various countries is available (Laparra and Pérez, 2012; Fun-

\footnotetext{
* Maria Carmen Sánchez-Sellero, Faculty of Economics and Business Administration, Department of Applied Economics, University of A Coruña, Campus de Elviña 15071 A Coruña, A Coruña (03082), Spain (ES), c.sanchez@udc.es
} 
dación FOESSA, 2014; Faura-Martínez et al., 2016; Annoni and Weziak-Bialowolska, 2016; Michálek and Výbošt’ok, 2019, among others). In the light of the poverty indicators studied in recent years, we believe that this topic is unquestionable today and that is our motivation for this research.

The concept of "poverty" refers to the difficulty of people to gain access to the necessary goods and services to ensure a decent quality of life and a satisfactory personal and social development. The existence of an "insufficient" income is one of the determinants of poverty, but is it not the only one nor does it include all the implications of "being poor" (Herrero, Soler and Villar, 2013).

The work we present is part of this premise, that income is not the only variable that explains poverty. A series of characteristics translated in terms of variables that add explanations to the different types of poverty can be added to it. This study allows you to find out what are the vulnerable groups that suffer some type of poverty. The importance of this study lies in the fact that strategies to reduce poverty must identify the factors that are strongly related to it. In the empirical analysis we will use the microdata from the Survey of Living Conditions (EU-SILC) of the year 2015, compiled by the INE (Instituto Nacional de Estadística, National Statistics Institute) in 2016.

Even though there is descriptive evidence on the socioeconomic profiles of the poor in Spain for 2015, the originality of this work is not only to study the relationship between the rates of poverty and certain demographic characteristics of the Spanish population in the year 2015, but also the way to classify individuals according to whether they have severe poverty level, moderate poverty level or do not have a risk of poverty. The objective is to detect which are the groups of the pop- ulation more likely to fit into some kind of poverty according to gender, marital status, country of birth, age, level of studies, the relationship with the activity and the type of contract. In addition, the study is innovative because it applies an ordinal logistic regression model to the recent data of EUSILC, which will allow us to estimate the probabilities that an over-16 individual is in a situation of moderate poverty, severe poverty, or with no risk of poverty for the different categories analysed.

In section 2 we present a review of the theoretical framework on the issue of poverty rates in Spain in recent years and its determinants. The section 3 is broken down into several parts: first, a study of the income per unit of consumption (or equivalent income) in the different groups in 2015; then it describes the variables, the data and the specification of the ordinal logistic regression model, with its results and discussion. And in the section 4 there are the conclusions of the work.

\section{POVERTY: EVOLUTION AND DETERMINANT FACTORS}

On 3rd March 2010 the European Commission released a communication entitled "Europe 2020 strategy for smart, sustainable and inclusive growth", in which the goals needed to coordinate a model of economic and social growth for its 27 member states are gathered (see Pagliacci 2017). In the field of social integration, the EU initiative "European Platform against poverty" was created with the aim "to ensure social and territorial cohesion in such a way that the benefits of growth and employment come to all, and that people affected by poverty and social exclusion can live with dignity and participate actively in society" (European Commission, 2010). In this direction, the EU's objective was to reduce the number of Europeans living below the national poverty line by 20 million people 
and, in the case of Spain, the contribution agreed to achieve the target demands to reduce the number of people at risk of poverty or social exclusion by 1.4 million by the year 2020.

The AROPE rate (At risk of poverty or social exclusion), which is part of the indicators of the strategy Europe 2020 and the rate of poverty ${ }^{1}$ are different indicators, because they measure different things. The first measures poverty and social exclusion and the second only poverty. "At risk of poverty or social exclusion, abbreviated as AROPE, corresponds to the sum of persons who are either at risk of poverty, or severely materially deprived or living in a household with a very low work intensity. Persons are only counted once even if they are present in several sub-indicators". The poverty rate is the share of people with an equivalised disposable income (after social transfer) below the at-risk-of-poverty threshold, which is set at $60 \%$ of the national median equivalised disposable income after social transfers (EUROSTAT, 2018). These definitions imply that the people who are in a situation of poverty are also recorded in the AROPE indicator, but it is possible that people included in this latest one are not poor ${ }^{2}$. In this paper we are going to refer only to the poverty rate.

Poverty is confirmed to be a multi-faceted phenomenon with clear within-country variability (Annoni and Weziak-Bialowolska, 2016). In literature there are different ways to deal with poverty measurement, depending on the nature of the poverty lines used, the type of primary variable taken as a reference, the temporal dimension, etc.
(Herrero, Soler and Villar, 2013; Kwadzo, 2015). Compared to the most traditional definitions of poverty, which put the emphasis on the insufficiency of income and in the material standard of living as determinant factors, other approaches have emerged as the "poverty in terms of capacities" or "social exclusion", which take a broader perspective. These new approaches have in common, in front of the conventional based on income, the claim of the multidimensional nature of poverty (EAPN, 2014).

Cantó, Gradin and Del Rio (2012) assert that poverty rates in Spain have persistently been at around $18-20 \%$ of the population since the early 1990s. Bárcena and Cowell (2006) focus on the static and dynamic poverty in Spain. The results confirm the pattern of changes in poverty observed by other authors for the early 1990s. After this period, poverty is slightly reduced, but 2000 is the point of change. In the dynamic perspective, the observed pattern is very mobile (ups and downs), but mostly in short periods of time.

If we go over the poverty rates in Spain in recent years, it is important to point out that the economic boom years did not bring associated reductions in the incidence of poverty, as it remained at around $20 \%$ between the years 2004 and 2007. However, the arrival of the crisis boosted a substantial rise of it between the years 2007 and $2012^{3}$, which shows, once again, that the poor are the first group to feel the consequences of the economic crisis and the last to receive the benefits of economic growth. The remarkable growth of poverty in the last year studied has dispelled the illusion of the

\footnotetext{
${ }^{1}$ According to EAPN (2015).

${ }^{2}$ There may be a case of people belonging to households with low-work intensity who are paid unemployment benefits, which keep the household income above the poverty line.

${ }^{3}$ Since that year, the new methodological model introduced by the INE (base 2013) prevents a comparison with previous years. The new model reduced the impact of the crisis in values ranging between 0.7 and 1.2 percentage points. Between 2009 and 2012, with the old methodology, the new poor are 1,096,994, and, with the new calculation model they amount to 295,042 , that is to say, 800,000 people are no longer counted as poor.
} 
maintenance of the rates during the crisis. Thus, the poverty rate has experienced an increase of $1.8 \%$, which, whatever the basis or methodology used, has been at its highest value and with the highest annual growth since the index ${ }^{4}$ was first calculated. In absolute terms, in the year 2014 the number of people at risk of poverty was about 10,380,000 people (EAPN, 2015). The rates of poverty in Spain that had previously been kept in the range of 18-20\% increased in these years to move around a $22 \%$. Concretely, in the year 2008 it stood at $19.8 \%$, while in 2016 the percentage was $22.3 \%$ (INE, 2018).

Numerous studies confirm the increase in poverty and social exclusion in Spain since 2008, as a result of the economic crisis (Laparra and Pérez, 2012; Pérez, 2013; Castel, 2014; Fundación FOESSA, 2014; EAPN, 2015; Faura-Martínez et al., 2016).

Having checked that the economic crisis brought about an increase in poverty rates, our purpose is to identify the most vulnerable groups. In order to study the risk of poverty in Spain, it is necessary to consider a number of factors linked to it, such as personal, family and labour characteristics of the people who are members of the Spanish population. The social policies and programs are designed for different groups, and that is the reason why we consider it essential to know the impact of poverty on different social groups. The EAPN report (2015) supports our theory, as it stated that during the period studied (2009-2014), the evolution of poverty has been different in function of sex, age groups, nationality, relationship with the activity and the level of training. Therefore, in the empirical analysis of poverty for the year 2015, we will introduce all these variables, to which we will add the marital status and type of contract (in case of being employed). In Cantó,
Gradin and Del Rio (2012), the variables of education and labour insertion of the households are said to be the main determinants of the different types of poverty.

The main findings of Ayllón (2013) show that about $50 \%$ of the probability of being poor in a given period is due to the past experiences of poverty in Spain; there is an important healing effect by which poor individuals enter into a vicious circle from which it is difficult to escape. Poverty is positively linked to a parent with a low level of education, of immigrant origin and with adolescents at home. Outside of Spain, we refer to the following works: Sekhampu (2013) estimated a logistic regression with the economic status (poor and nonpoor) as the dependent variable and a set of demographic variables as explanatory variables. The results show that the household size, age and employment status of the head of the family explain significant variations in the probability of being poor; the strongest indicator of poverty is the employment status of the head of the family. Along that line Mberu et al. (2014) identify the neighbourhoods of residence, sex and marital status of the head of the family, the achievement of at least secondary education for the head of the family, stability in employment, household size, and the incidence of births at home, among the main determinants of transitions to the poverty of households. For Lekobane and Seleka (2016), the type of studies and employment status of the head of the family are among the main determinants of household welfare and poverty. Dartanto and Nurkholis (2013) confirmed that the causal factors of the dynamics of poverty are the level of studies, the number of household members, assets, employment status, health problems, the microcredit program, access to electricity, and changes in employment. Other works

\footnotetext{
${ }^{4}$ The Survey of conditions of life begins in 2004.
} 
that analyse the determinants of poverty in different countries are those of Chen and Wang (2015), Herman (2014), Dafermos and Papatheodorou (2013), Achia, Wangombe and Khadioli (2010), Amuedo-Dorantes (2004), among others. A vision of poverty data in the countries of the EU can be found in EUROSTAT (2016a, 2016b).

The above references allow us to assert that the factors may vary depending on the area in which we do the study, although most of authors agree that gender, age, the level of studies, marital status and employment status are determinants of poverty.

\section{EMPIRICAL STUDY OF POVERTY}

In this section we will make an empirical study of poverty using the EU-SILC (Survey on living conditions) of the year 2015 (INE, 2016). To do this, in the first place we define the variable equivalent income, which is necessary for the calculation of the rates of poverty. In order to know how the income is distributed among different social groups, we make a descriptive analysis of the income quintiles. Secondly, we calculate the different rates of poverty (severe poverty, moderate poverty) for these groups. Subsequently, and by using the ordinal logistic regression model, we try to estimate the risk of poverty (severe, moderate, with no risk) on the basis of sex, marital status, country of birth, etc., calculating not only the resulting coefficients of the model, but also the estimated probabilities for each of the categories of the variables involved in this process.

\section{Data and variables}

The data used come from the EU-SILC for the year 2015. This survey is included in the European project EU-SILC (European Union Statistics on Income and Living Conditions) the purpose of which is to provide harmonized statistics for all countries of the
European Union on the income distribution of households and on various aspects of the standard of living of households and social exclusion. This annual survey has been carried out since the year 2004, and although the priority is to provide cross-sectional information on the conditions of life, it also provides longitudinal information due to the fact that the design of this survey is a rotating panel (in the Spanish case, the sample is made of four independent sub-samples, each of which is a four-year panel, and each year a panel is renewed). The EU-SILC is addressed to private households who reside in private family housing, therefore, the homeless and those living in institutions or in group homes are outside the scope of the study, and those people are most affected by poverty. Many of the questions about the conditions of life in this survey refer to the time of the interview; however, the information on income refers to the previous calendar year.

The microdata from the EU-SILC provide information about 12,367 Spanish households surveyed in the year 2015. It also provides information on the people who live in these households. For this reason, we had to create a unified file that contains all the information for people over 16 years and the households where they live. In particular, we have a sample of 32,381 people and we have the most detailed information for 27,215 people over the age of 16 , representing $38,517,183$ in the total population.

One of the objectives of this work is to study poverty in terms of a set of demographic and socio-economic variables, since it is of great interest in the analysis of poverty to study how the poor are distributed on the basis of their sex, marital status, etc. Table 1 contains all the studied variables with their different categories indicating the percentage that each one of them represents in the Spanish population over the age of 16. 
Table 1

Variables studied and percentages by categories (people aged 16 and over)

\begin{tabular}{|c|c|}
\hline \multirow{2}{*}{ Gender } & Men $48.7 \%$ \\
\hline & Women $51.3 \%$ \\
\hline \multirow{5}{*}{$\begin{array}{l}\text { Marital } \\
\text { status }\end{array}$} & Single $32.5 \%$ \\
\hline & Married 53.3\% \\
\hline & Separated $2.3 \%$ \\
\hline & Widower $8.1 \%$ \\
\hline & Divorced $3.8 \%$ \\
\hline \multirow{3}{*}{$\begin{array}{l}\text { Country of } \\
\text { birth }\end{array}$} & Spain $88.4 \%$ \\
\hline & Rest of EU $3.7 \%$ \\
\hline & Rest of the world $7.9 \%$ \\
\hline \multirow{4}{*}{ Age } & From 16 to 25 years $11.7 \%$ \\
\hline & From 26 to 45 years $36.3 \%$ \\
\hline & From 46 to 65 years $31.6 \%$ \\
\hline & Over 65 years $20.3 \%$ \\
\hline \multirow{4}{*}{$\begin{array}{l}\text { Level of } \\
\text { studies }\end{array}$} & Illiterate and Primary studies $25.3 \%$ \\
\hline & Secondary studies $46.6 \%$ \\
\hline & Post-Secondary studies $0.2 \%$ \\
\hline & University studies $27.9 \%$ \\
\hline \multirow{5}{*}{$\begin{array}{l}\text { Relationship } \\
\text { with the } \\
\text { activity }\end{array}$} & Salaried $38.1 \%$ \\
\hline & Self-employed $7.5 \%$ \\
\hline & Unemployed $15.6 \%$ \\
\hline & Retired $16.4 \%$ \\
\hline & Other inactive $22.3 \%$ \\
\hline \multirow{4}{*}{$\begin{array}{l}\text { Professional } \\
\text { situation }\end{array}$} & Employer $4.0 \%$ \\
\hline & $\begin{array}{l}\text { Entrepreneur without employees } \\
11.25 \%\end{array}$ \\
\hline & Salaried $83.7 \%$ \\
\hline & Familiar help $1.0 \%$ \\
\hline \multirow{2}{*}{$\begin{array}{l}\text { Type of } \\
\text { contract }\end{array}$} & Permanent job $66.1 \%$ \\
\hline & Temporal job 33.9\% \\
\hline
\end{tabular}

Source: Own elaboration based on the Survey of Living Conditions (2015).

\section{Study of the income per unit of consumption (or equivalent income)}

One of the major decisions in studies on poverty is to define the monetary variable to serve as a basis for the calculation of poverty. In this work, we use the income per unit of household consumption, which is obtained by dividing the total household disposable income by the number of units of consumption that form this household (to calculate the number of household consumption units using the modified OECD scale $^{5}$ ). Subsequently, we attach this income to each of the members of the household and this income per consumption unit of persons (or equivalent income of the person) will be the main variable to calculate the risk of poverty.

We are interested in finding out what are the percentages of income for the different characteristics of the population, that is to say, to know what range of income people have according to their gender, marital status, etc. The study of the quintiles lets you get closer to the income inequality of the Spanish population. The research on the dynamics of poverty points to Spain as a country with a high mobility of income, both for entering into or going out of poverty, and with a high percentage of the population that at some point was below the poverty line. In Cantó (2000) it is proved that $60 \%$ of the Spanish households change their income and therefore they can change the decile from one year to the next. In this line, Ayala and Sastre (2008) conclude that Spain has a higher rate of poverty than other countries in the European Union (EU) and

\footnotetext{
${ }^{5}$ That assigns a weight of 0.5 to the other adults in the household and a weight of 0.3 to children under the age of 14 years old. Thus, a person living alone constitutes a unit of consumption, a household composed by two adults are 1.5 units of consumption and a household consisting of two adults and two children are 2.1 units of consumption.
} 
simultaneously has a greater mobility of people in low and middle income, together with a low mobility between those at the top of the distribution. The authors attribute this to the strong segmentation of the Spanish labour market as the most influential factor in these results.

To calculate the distribution of the population into quintiles according to their income, all the people are sorted depending on the amount of the income per unit of consumption and the income quintiles are calculated (five equal groups). The distribution of income according to the quintiles can be disaggregated on the basis of variables such as gender, marital status, country of birth, etc. (see Table 2).
With regard to gender, there are no major differences between men and women. In civil status, the 30.3 and $28.6 \%$ of the income of separated and divorced respectively were in the first quintile. Also, the 29.9 per cent of young people aged 16-25 years are found in the first quintile. In terms of the level of studies, it is emphasized that the $41.8 \%$ of those with higher education are in the quintile 5 (20\% of higher-income). With regard to the activity, the $41.5 \%$ of the unemployed are in the quintile 1 . With regard to the professional situation, in the quintiles 1 and 2 we can find most of people $(29.7+36.2 \%)$ who receive the family allowance. With regard to the type of contract, the $30.7 \%$ of people with a fixed

Table 2

Population by income quintiles per consumption unit according to characteristics (\%)

\begin{tabular}{|c|c|c|c|c|c|c|}
\hline & \multicolumn{5}{|c|}{$1^{\circ}$ Quintile $2^{\circ}$ Quintile $3^{\circ}$ Quintile $4^{\circ}$ Quintile $5^{\circ}$ Quintile } \\
\hline & & $0-20 \%$ & $20-40 \%$ & $40-60 \%$ & $60-80 \%$ & $80-100 \%$ \\
\hline \multirow{2}{*}{ Gender } & Men & 19.2 & 19.0 & 19.9 & 20.6 & 21.2 \\
\hline & Women & 18.4 & 21.1 & 20.6 & 20.2 & 19.6 \\
\hline \multirow{5}{*}{ Marital status } & Single & 22.4 & 18.8 & 19.2 & 19.9 & 19.6 \\
\hline & Married & 16.6 & 19.3 & 20.6 & 21.2 & 22.3 \\
\hline & Separated & 30.3 & 19.4 & 17.4 & 20.4 & 12.5 \\
\hline & Widower & 10.9 & 31.1 & 23.7 & 20.0 & 14.2 \\
\hline & Divorced & 28.6 & 20.2 & 18.8 & 14.5 & 17.9 \\
\hline \multirow{3}{*}{$\begin{array}{l}\text { Country of } \\
\text { birth }\end{array}$} & Spain & 16.1 & 19.7 & 20.7 & 21.5 & 22.0 \\
\hline & Rest of EU & 28.4 & 24.5 & 21.6 & 13.6 & 11.9 \\
\hline & Rest of the world & 45.3 & 22.6 & 15.1 & 10.6 & 6.4 \\
\hline \multirow{4}{*}{ Age } & From 16 to 25 years & 29.9 & 21.4 & 19.2 & 15.1 & 14.4 \\
\hline & From 26 to 45 years & 20.0 & 18.1 & 18.7 & 22.1 & 21.2 \\
\hline & From 46 to 65 years & 18.9 & 17.9 & 19.3 & 19.8 & 24.1 \\
\hline & Over 65 years & 10.2 & 26.5 & 25.2 & 21.4 & 16.7 \\
\hline \multirow{4}{*}{$\begin{array}{l}\text { Level of } \\
\text { studies }\end{array}$} & Illiterate and primary studies & 22.3 & 29.6 & 23.3 & 17.3 & 7.5 \\
\hline & Secondary studies & 22.9 & 20.8 & 21.7 & 20.1 & 14.6 \\
\hline & Post-Secondary studies & 16.7 & 25.7 & 15.8 & 30.3 & 11.5 \\
\hline & University studies & 8.9 & 10.4 & 15.2 & 23.6 & 41.8 \\
\hline \multirow{5}{*}{$\begin{array}{l}\text { Relationship } \\
\text { with the } \\
\text { activity }\end{array}$} & Salaried & 10.9 & 15.3 & 19.8 & 25.5 & 28.6 \\
\hline & Self-employed & 25.1 & 17.0 & 18.2 & 18.2 & 21.4 \\
\hline & Unemployed & 41.5 & 23.7 & 17.0 & 10.8 & 7.0 \\
\hline & Retired & 8.2 & 21.8 & 24.1 & 22.2 & 23.7 \\
\hline & Other inactive & 22.2 & 25.8 & 21.2 & 17.7 & 13.1 \\
\hline \multirow{4}{*}{$\begin{array}{l}\text { Professional } \\
\text { situation }\end{array}$} & Employer & 16.9 & 16.1 & 19.2 & 20.0 & 27.9 \\
\hline & Entrepreneur without employees & 23.0 & 24.1 & 21.1 & 17.3 & 14.4 \\
\hline & Salaried & 16.6 & 18.5 & 20.5 & 21.9 & 22.5 \\
\hline & Familiar help & 29.7 & 36.2 & 13.2 & 13.3 & 7.7 \\
\hline \multirow{2}{*}{$\begin{array}{l}\text { Type of } \\
\text { contract }\end{array}$} & Permanent job & 8.2 & 14.2 & 20.9 & 26.1 & 30.7 \\
\hline & Temporal job & 30.6 & 25.7 & 20.1 & 15.0 & 8.6 \\
\hline
\end{tabular}

Source: Own elaboration based on the Survey of Living Conditions (2015). 
contract are framed within the quintile 5 (higher incomes), while the workers with a temporary contract belong to the quintile 1 (with the lowest incomes) with a similar percentage $(30.6 \%)$

A study on the effects of the recessive stage (Ayala, 2013) confirms that the fall of the incomes tends to affect mainly the households with incomes more dependent on the labour market. The available data from 2007 seem to indicate that in many countries men have suffered greater losses of employment and income than women, also confirming the biggest problems for workers with lower age and training.

In summary, in view of the previous study based on the amounts of the equivalent income per person we can guess that the most vulnerable groups are formed by separated and divorced, non-European foreigners, young people, persons with little training, the unemployed, those who receive family allowance and workers with a temporary contract.

\section{Study of the rates of poverty according to socio-economic characteristics}

Poverty studies classify people as poor and non-poor depending on whether their income per unit of consumption (or equivalent income of the person) is below or above a poverty line. The generally accepted criterion to determine the poverty line is the $60 \%$ of the median income (EUROSTAT, 2016c; INE, 2006). Within this population considered as poor, we are interested in differentiating between people who are in a situation of severe poverty or moderate poverty. Therefore, we do not set a single poverty line but two of them, in such a way that a person is in a situation of severe poverty if their income does not reach $30 \%$ of the median equivalent income or in a situation of moderate poverty if it is between $30 \%$ and $60 \%$ of this median income. Authors such as Arranz and García-Serrano (2009) have already used two lines ${ }^{6}$ placing severe poverty below $40 \%$ of median income. However, we believe that it would be more appropriate to use the $30 \%$ following the criterion of EAPN (2015): in this report the thresholds of $30 \%$ and $60 \%$ are used to catalogue poverty. In Spain in the year 2015 the line that delimits the severe poverty is 4,005.5 euros which represents $7.6 \%$ of the population, while $14.5 \%$ of the population is in moderate poverty, with $8,010.9$ euros as the figure that delimits the risk of being or not being in a situation of poverty.

In this work we attempt to identify the economic and social profiles where poverty is more beset, therefore we classify the total population in terms of various socio-economic characteristics, and this information can only be obtained for the population over the age of 16 , with the poverty rate for persons over 16 years in the year 2015 of $21 \%$. Moreover, we are interested in quantifying the incidence of poverty by differentiating between severe and moderate poverty; these rates are placed at $6.9 \%$ and $14.1 \%$, respectively. In Figure 1 we show the rates of severe and moderate poverty for different groups of the population in terms of the variables studied.

\footnotetext{
${ }^{6}$ It is also possible to use other lines or cutting lines on the basis of which people are considered to be in severe poverty (for example, below the $20 \%$ or $25 \%$ of the median incomes of the population).
} 
Figure 1

Severe and moderate poverty rates according to the different characteristics, 2015

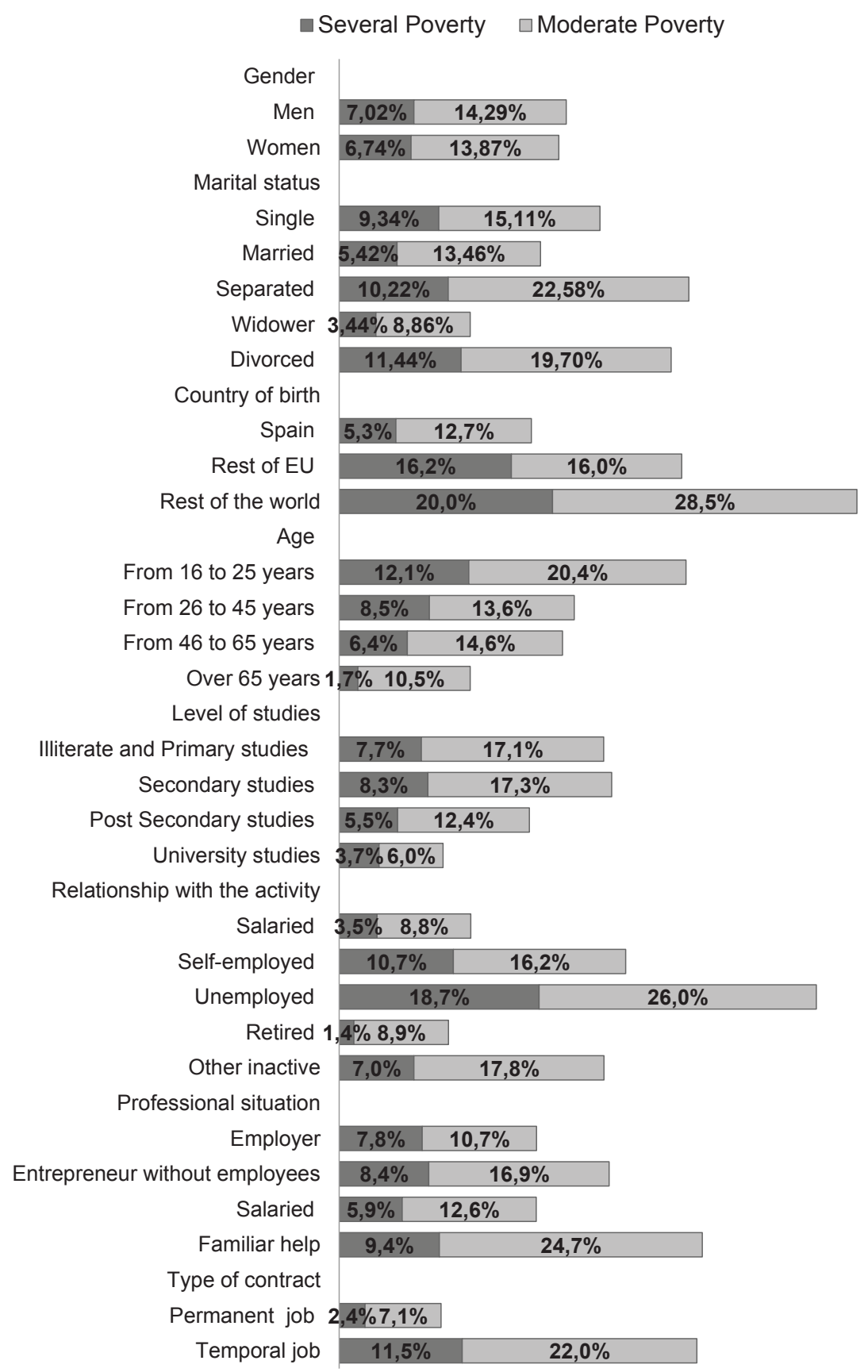

Source: Own elaboration based on the Survey of Living Conditions (2015). 
With regard to gender, the risk of poverty is similar for men and women; with regard to the marital status it is highlighted that the higher rates of poverty risk occur among the separated and divorced people, widowers recorded lower rates, and those being married and unmarried are in an intermediate place, therefore, those who have a love life and this life breaks up are more exposed to the risk of poverty. With regard to the country of birth, the risk of poverty rate, both severe and moderate, shot up for people born outside the European Union, standing at $48.5 \%$ compared to the citizens born in the European Union at $32.2 \%$, while the lowest rate is for the Spaniards at $18 \%$, which seems to indicate that among the population that resides in Spain the fact of being a foreigner is a factor that raises the risk of poverty. With regard to the age and level of studies, a marked negative relation is shown between these variables and the incidence of poverty. In the level of education, the people with higher education are clearly at a lower risk of poverty, at the rate of $9.7 \%$ compared to $24.8 \%$ for people with low level of education (primary or less).

In the analysis of labour characteristics, in the variable relation with the activity the high risk of poverty rate of the unemployed of $44.7 \%$ is pointed out, compared to the lowest rate of the retirees of $10.3 \%$. It is surprising that retirees are in a better position to tackle poverty than the active population (both employed and unemployed). With regard to the professional situation (this refers to the occupied population), individuals with family allowance have the highest rates, whereas the employees, self-employed and employers have lower rates. Finally, the fixed-term contract workers are in a situation much more favourable to the risk of poverty than workers with a temporary contract.

\section{Specification of the model}

The risk that a person has to be in a situation of poverty is influenced by a large number of variables, which are interrelated. Therefore, it is difficult to isolate the individual effect of each of them separately. To determine the risk of a person to be found in a situation of severe poverty, moderate poverty or with no risk of poverty, maintaining the influence of other variables constant, it is necessary to work with techniques of multivariate analysis. We use an ordinal logistic regression model that is appropriate when the dependent variable has more than two categories and it is an extension of the classical binary logistic regression.

The primary objective that this technique solves is to model how a set of explanatory variables (dichotomous, nominal and/or categorical) influences on the probability of occurrence of an event, usually dichotomous, but in this case polytomous. That is to say, to estimate the probability of an occurrence of each of the possibilities of an event with more than two categories.

We consider the dependent variable, which measures 3 categories (with no risk of poverty, moderate poverty or severe poverty) according to the following scheme:

$$
Y_{i}=\left\{\begin{array}{rrr}
1 & Y_{i}^{*} \leq \alpha_{1} \\
2 & \alpha_{1}<Y_{i}^{*} \leq \alpha_{2} \\
3 & Y_{i}^{*}>\alpha_{2}
\end{array}\right.
$$

How $Y_{i}$ take the values 1, 2 and 3 are two thresholds $\alpha_{1}$ and $\alpha_{2}$, being $Y_{i}^{*}$ the equivalent income. The probability that the variable $\mathrm{Y}_{\mathrm{i}}$ takes the values 1,2 or 3 in the presence of the explanatory variables $X$, being $X=\left(x_{1}, x_{2}, x_{3}, \ldots, x_{k}\right)$ can be calculated using the following relationship:

$$
\begin{gathered}
P\left(Y_{i}=1 / X\right)=P\left(Y_{i}^{*} \leq \alpha_{1} / X\right)=P\left(X \beta+u \leq \alpha_{1} / X\right)=F\left(\alpha_{1}-X \beta\right) \\
P\left(Y_{i}=2 / X\right)=P\left(\alpha_{1}<Y_{i}^{*} \leq \alpha_{2} / X\right)=F\left(\alpha_{2}-X \beta\right)-F\left(\alpha_{1}-X \beta\right) \\
P\left(Y_{i}=3 / X\right)=P\left(Y_{i}^{*}>\alpha_{2} / X\right)=1-F\left(\alpha_{2}-X \beta\right)
\end{gathered}
$$

where $\mathrm{F}$ is the cumulative distribution function of the logistic equation. The values of 
$\alpha$ and $\beta$ are calculated by the maximum likelihood method.

\section{Results and discussion of the model}

In Table 3 we can find the estimates of the parameters of the ordinal logistic regression model. The coefficients for the marital status indicate that the separated and divorced have a greater chance of poverty than single, married and widowed persons by the positive sign of its coefficients; people whose country of birth is the rest of the world are more likely to incur poverty than the Spaniards and other Europeans; the same happens to the youngest people, those with less training and those with a temporary contract.

With regard to the ratios of probability $(\operatorname{Exp}(b))$, the negative coefficients will have odds ratios less than 1 and the positive, are greater than 1 . In order to enable the comparison of all $\operatorname{Exp}(b)$, in those smaller than 1 its inverse is calculated. In this way, keeping all other variables constant, the separated have a chance to be in poverty that is 1.225 times higher than that of the divorced (as this is the reference category in that variable); those who are Spaniards are less likely to be in poverty than the citizens of the rest of the world, being 1/0.304=3.289 times less likely to come into poverty.

Table 3

Estimates of the parameters (Ordinal logistic regression model)

\begin{tabular}{lccc}
\hline & $b$ & STD & Exp(b) \\
\hline Gender & & & \\
\hline Men & $0.426^{\star}$ & 0.001 & 1.531 \\
\hline Women & $0^{\mathrm{a})}$ &. &. \\
\hline Marital status & & & \\
\hline Single & $-0.594^{*}$ & 0.003 & 0.552 \\
\hline Married & $-0.394^{\star}$ & 0.003 & 0.675 \\
\hline Separated & $0.203^{\star}$ & 0.004 & 1.225 \\
\hline Widower & $-0.613^{\star}$ & 0.004 & 0.542 \\
\hline Divorced & $0^{\mathrm{a}}$ &. &. \\
\hline
\end{tabular}

Table 3. Continued

\begin{tabular}{|c|c|c|c|}
\hline & $\mathrm{b}$ & STD & $\operatorname{Exp}(b)$ \\
\hline \multicolumn{4}{|l|}{ Country of birth } \\
\hline Spain & $-1.192^{*}$ & 0.002 & 0.304 \\
\hline Rest of EU & $-0.323^{\star}$ & 0.003 & 0.724 \\
\hline Rest of the world & $0^{\mathrm{a}}$ & . & . \\
\hline \multicolumn{4}{|l|}{ Age } \\
\hline $\begin{array}{l}\text { From } 16 \text { to } 25 \\
\text { years }\end{array}$ & $0.506^{\star}$ & 0.004 & 1.658 \\
\hline $\begin{array}{l}\text { From } 26 \text { to } 45 \\
\text { years }\end{array}$ & $0.821^{\star}$ & 0.003 & 2.272 \\
\hline $\begin{array}{l}\text { From } 46 \text { to } 65 \\
\text { years }\end{array}$ & $0.524^{\star}$ & 0.003 & 1.689 \\
\hline Over 65 years & $0^{\text {a) }}$ & . &. \\
\hline \multicolumn{4}{|l|}{ Level of studies } \\
\hline $\begin{array}{l}\text { Illiterate and } \\
\text { Primary studies }\end{array}$ & $1.077^{\star}$ & 0.002 & 2.935 \\
\hline $\begin{array}{l}\text { Secondary } \\
\text { studies }\end{array}$ & $0.706^{\star}$ & 0.002 & 2.025 \\
\hline $\begin{array}{l}\text { Post-Secondary } \\
\text { studies }\end{array}$ & $0.875^{\star}$ & 0.014 & 2.399 \\
\hline University studies & $0^{\mathrm{a}}$ & . & . \\
\hline \multicolumn{4}{|l|}{$\begin{array}{l}\text { Relationship with } \\
\text { the activity }\end{array}$} \\
\hline Salaried & $1.172^{\star}$ & 0.002 & 3.230 \\
\hline Self-employed & $1.710^{*}$ & 0.011 & 5.528 \\
\hline Unemployed & $1.120^{\star}$ & 0.002 & 3.066 \\
\hline Retired & $-0.660^{\star}$ & 0.003 & 0.517 \\
\hline Other inactive & $0^{\text {a) }}$ & . & . \\
\hline \multicolumn{4}{|l|}{ Type of contract } \\
\hline Permanent job & $-0.507^{\star}$ & 0.001 & 0.603 \\
\hline Temporal job & $0^{\text {a) }}$ & . & . \\
\hline \multicolumn{4}{|l|}{ Thresholds } \\
\hline Limit 1 & 0.831 & 0.005 & 2.295 \\
\hline Limit 2 & 2.499 & 0.005 & 12.168 \\
\hline
\end{tabular}

Note: * significance $1 \%$.

a) This parameter has been set to zero because it is redundant.

Source: Own elaboration based on the Survey of Living Conditions (2015).

The final model presents the goodnessof-fit tests: Pseudo $\mathrm{R}^{2}$ of Cox and Snell equal to 0.251 , Nagelkerke of 0.367 and McFadden of 0.251 , values which we consider appropriate, and which reflect a correct explanatory capacity of the model. 
These results are compatible with those published by the EAPN (2015) with regard to the variables of gender, age, nationality, relation with the activity and the level of education. These are the following: 1) crisis, or better said the policy implemented to fight the crisis, makes the percentages of poverty in both sexes the same. 2) In line with other indicators studied, the risk of poverty has experienced a sharp increase for all age groups, except for the population over the age of 65 years, which enjoys a relatively fixed income in the form of pensions $\left.^{7} .3\right)$ With regard to nationality ${ }^{8}$, if the evolution from the year 2009 is growing for all, it is much more for the foreign population from outside the EU; since that year, the risk-of-poverty rate among the foreign population from the EU has almost doubled that of the Spanish population, and that rate in non-European countries population has tripled. 4) In the variable relation with the activity, the poverty rate grows in the year 2014 for all groups of working population and it continued to decline for the group of retirees. Also as expected, between 2009 and 2014, poverty rates are very high for the unemployed (whose rate reaches more than $45 \%$ in 2014) and the lowest rates correspond to the occupied population. It is important to note here the high figures of poverty that affect the occupied population which questions the idea that the best antidote to poverty is work, since it is simply not true that any work protects them against poverty. In this regard, the 2.5 percentage points of the increase in poverty among the occupied that occurred in the last year should be emphasized especially, which coincides with the decline in the unemployment figures. In terms of the level of studies, the higher is the level of training, not only the less the rate of poverty that affects a person is, but also the less pronounced the influence of the crisis in the growth of the indicator has been.

There are many studies that deal with the influence of gender on poverty. Following a review of the empirical literature that has linked gender to poverty since the second half of the 1990s to the present, the main conclusion that Oliveri makes (2013) is that, as a result of the lack of agreement on definitions and methodologies, in many cases radically different results are obtained. As an example, Zarzosa (2002) gets high levels of poverty inequality between men and women, while in Maestro and Martinez (2003), the differences are the smallest in the whole sample. Chant (2006) interprets the feminization of poverty through three statements: women account for a higher percentage within the group of the poor, this trend is accentuated, and the increasing development of the number of women in poverty is associated to a higher incidence of poverty in households that have a woman as their main breadwinner. However, although Belzunegui, Pastor and Valls (2011) observe higher rates of poverty in women than in men, on their empirical basis they put into question that the differential suffices to say that there is a feminization of poverty, understood as a process in which the gap between the male and female poverty will get wider. The data indicate that poverty rates between men and women shorten their differences and, therefore, could it be said that the feminization of poverty is being reduced, or the data are influenced by the current context of crisis that makes men more vulnerable to poverty?

In Table 3 it can be seen that foreign non-European people have more poverty

\footnotetext{
${ }^{7}$ However, recent studies have shown that a part of the households headed by older people are supporting other younger family members (children and/or grandchildren) with their income. The result is a significant reduction in the disposable income of the elderly that is not reflected in poverty indicators.

${ }^{8}$ Our variable is not nationality, it is the country of birth.
} 
than the Spanish ones. Our result is compatible with Hooijer and Picot (2015), where they claim that in almost all European welfare states, immigrants are facing a higher risk of poverty than the natives.

From the estimation of the model, we assess the probabilities of the corresponding estimated answers to each of the categories of explanatory variables (see Table 4). having no risk of poverty. With regard to the marital status, the separated are those who are more likely to be at risk of poverty $(0.1738+0.1128=28.66 \%)$. As to the country of birth, non-European foreigners are at a greater risk of poverty (42.74\%). With respect to other variables, the youngest are more at risk of poverty, i.e. 16-25 years (26.37\%), as well as those with a lower ed-

Table 4

Estimated probabilities of the poverty categories by ordinal logit

\begin{tabular}{|c|c|c|c|c|}
\hline & & $\begin{array}{c}\text { Without Risk } \\
\text { of Poverty }\end{array}$ & $\begin{array}{c}\text { Moderate } \\
\text { Poverty }\end{array}$ & $\begin{array}{l}\text { Severe } \\
\text { Poverty }\end{array}$ \\
\hline \multirow{2}{*}{ Gender } & Men & 0.8197 & 0.1204 & 0.0599 \\
\hline & Women & 0.8235 & 0.1246 & 0.0519 \\
\hline \multirow{5}{*}{ Marital status } & Single & 0.8015 & 0.1376 & 0.0609 \\
\hline & Married & 0.8369 & 0.1124 & 0.0507 \\
\hline & Separated & 0.7134 & 0.1738 & 0.1128 \\
\hline & Widower & 0.8884 & 0.0849 & 0.0267 \\
\hline & Divorced & 0.7395 & 0.1651 & 0.0953 \\
\hline \multirow{3}{*}{ Country of birth } & Spain & 0.8508 & 0.1073 & 0.0418 \\
\hline & Rest of EU & 0.6813 & 0.1979 & 0.1208 \\
\hline & Rest of the world & 0.5726 & 0.2489 & 0.1785 \\
\hline \multirow{4}{*}{ Age } & From 16 to 25 years & 0.7363 & 0.1829 & 0.0808 \\
\hline & From 26 to 45 years & 0.8025 & 0.1308 & 0.0668 \\
\hline & From 46 to 65 years & 0.8194 & 0.1250 & 0.0555 \\
\hline & Over 65 years & 0.9072 & 0.0734 & 0.0194 \\
\hline \multirow{4}{*}{ Level of studies } & Illiterate and Primary studies & 0.7570 & 0.1616 & 0.0815 \\
\hline & Secondary studies & 0.7789 & 0.1511 & 0.0700 \\
\hline & Post-Secondary studies & 0.8445 & 0.1131 & 0.0424 \\
\hline & University studies & 0.9197 & 0.0590 & 0.0213 \\
\hline \multirow{5}{*}{$\begin{array}{l}\text { Relationship with } \\
\text { the activity }\end{array}$} & Salaried & 0.8824 & 0.0814 & 0.0362 \\
\hline & Self-employed & 0.6717 & 0.1608 & 0.1675 \\
\hline & Unemployed & 0.5689 & 0.2769 & 0.1542 \\
\hline & Retired & 0.9116 & 0.0699 & 0.0185 \\
\hline & Other inactive & 0.7898 & 0.1583 & 0.0519 \\
\hline \multirow{2}{*}{ Type of contract } & Permanent job & 0.9034 & 0.0713 & 0.0253 \\
\hline & Temporal job & 0.6619 & 0.2221 & 0.1160 \\
\hline
\end{tabular}

Source: Own elaboration based on the Survey of Living Conditions (2015).

From Table 4 obtained using the ordinal logit model we can say that there is practically no difference in the estimated probabilities between men and women in ucational level (24.31\%), the unemployed $(43.11 \%)$ and those who have a temporary contract $(33.81 \%)$. 
The age and employment status of the head of the household reduce the probability of being poor, while the size of the household is associated to a higher probability of being poor, according to Sekhampu (2013). With regard to age, we share the idea of this author, because we see that in Table 4 the probability corresponding to the category "with no risk of poverty" is increasing as age increases, which indicates an inverse relationship between age and poverty.

A comparative analysis of vulnerable groups at risk of poverty (Gerovska-Mitev, $2015)$ in the analyzed three countries (Macedonia, Serbia and Croatia) shows a common pattern in relation to the unemployed and women. Age-related analysis shows that, while in Macedonia and Serbia the most vulnerable group at risk of poverty are children (0-17), in Croatia older people $(65+)$ are the ones at the greatest risk of poverty.

The above results are in line with those obtained by Cantó, Gradin and Del Rio (2012), where it is said that households with a low level of qualifications and with difficulties of labour insertion (lower number of income earners and occupations of lower qualification) are more likely to be recurrent or chronic poor. In addition, self-employment, due to its high volatility in income, is associated to a greater likelihood of recurrence in poverty. In our work, in the variable related to activity, the self-employed are the second with a higher risk of poverty (32.83\%), the unemployed recording the highest percentage (43.11\%). For Amuedo-Dorantes and Serrano-Padial (2010), temporary contracts expose workers to a higher risk of poverty due to the limited work stability, few opportunities for promotion and low wages. In no other country is the increase of flexible working arrangements more evident than in Spain, where nearly a third of the labour force has fixed-term contracts. The adverse impact of temporary employment is linked to the short duration of some contracts, which indicates the importance of the labour relationship.

\section{CONCLUSIONS}

Doing a review of poverty rates in Spain in recent years, we have been able to verify that the rates prior to the economic crisis remained in the range of $18-20 \%$, and increased in subsequent years to move around $22 \%$.

The various economic, political, social and mass media have highlighted the idea that the figures of poverty and inequality in Spain have increased in these years of crisis. Some consider that public policies based on the necessary budget cuts to deal with this recession are to blame for these increases in poverty rates. Without going into ratings of whom to blame for these increases, we must accept that in the situations of difficulty, there are some groups that due to their economic conditions are at a disadvantage to face adverse situations.

Once we have verified that the rates of poverty have really grown, our interest was to find out which groups are most affected by this situation, in other words, which demographic and labour characteristics are shown by the people who have higher poverty rates. Although this work was developed for only one year (2015), the conclusion would be broader if a dynamic analysis was carried out; this may be a task for the future. For this purpose we estimate an ordinal logistic regression model where the dependent variable is classified into three categories: no risk of poverty, moderate poverty and severe poverty. In general terms, the results of the applied methodology lead us to conclude that the probabilities of being in moderate or severe poverty between men and women hardly reflect any difference. The separated and divorced are those who have a higher risk of poverty, as well as foreign people from non-Europe- 
an countries. As to the age, the greater the age, the more the likelihood of poverty decreases. With regard to the level of studies the same happens, that is to say, the more training, the lower poverty rate. If we focus on employment characteristics, in relation with the activity, the unemployed are those who have the highest probability of falling into poverty (43.11\%). If the type of contract is temporary, the probability of experiencing moderate or severe poverty is greater than if the contract is for an indefinite period. $41.5 \%$ of the unemployed and $30.6 \%$ of those who have temporary contract are paid the lowest incomes (grounded in the first quintile of income); it is also striking that $65.9 \%$ of those who are paid family allowance are in the 2 lower income ranges.

Policies to fight against poverty in Spain should focus on breaking the spiral of poverty and, for this purpose, promoting social policies that strengthen protective factors in subjects such as education, training, housing, and so on. The strategies aimed at reducing poverty must identify the factors that are strongly related to it. In addition, to know the most vulnerable groups makes it possible to construct policies more adapted to solve this problem.

Therefore, public policies should focus on two basic pillars; on the one hand, education, since the intellectual wealth of a country is based on training, and, on the other hand, job creation, because in this way you are injecting economic wealth to the families. From our point of view, the intellectual wealth and economic wealth are the basis of the proper functioning of society. The question is how to implement appropriate policies to achieve both goals.

\section{REFERENCES}

Achia, T. N., Wangombe, A., \& Khadioli, N. (2010). A logistic regression model to identify key determinants of poverty using demographic and health survey data. European Journal of Social Sciences, 13(1), 38-45.
Amuedo-Dorantes, C. (2004). Determinants and poverty implications of informal sector work in Chile. Economic Development and Cultural Change, 52(2), 347-368. https://doi. org/10.1086/380926

Amuedo-Dorantes, C., \& Serrano-Padial, R. (2010). Labor market flexibility and poverty dynamics. Labour Economics, 17(4), 632-642. https://doi. org/10.1016/j.labeco.2010.01.004

Annoni, P. \& Weziak-Bialowolska, D. (2016). A measure to target antipoverty policies in the European Union regions. Applied Research in Quality of Life, 11(1), 181-207. https://doi.org/10.1007/ s11482-014-9361-z

Arranz, J. M., \& García-Serrano, C. (2009). Pobreza y mercado de trabajo en España. Estadística Española, 51(171), 281-329.

Ayala, L. (2013). Crisis económica y distribución de la renta: Una perspectiva comparada. Papeles de Economía Española, (135), 2-19.

Ayala, L., \& Sastre, M. (2008). The structure of income mobility: Empirical evidence from five EU countries. Empirical Economics, 35(3), 451-473. https://doi.org/10.1007/s00181-007-0172-z

Ayllón, S. (2013). Understanding poverty persistence in Spain. SERIEs, 4(2), 201-233. https://doi. org/10.1007/s13209-012-0089-4

Bárcena, E., \& Cowell, F. (2006). Static and dynamic poverty in Spain, 1993-2000. LSE STICERD Research Paper 77. https://ssrn.com/abstract $=1094869$

Belzunegui, A., Pastor, I., \& Valls, F. (2011). La pobreza, una cuestión femenina?: Pobreza y género en España en los datos de la ECV 2009. Revista Internacional de Trabajo Social y Ciencias Sociales, (2), 39-65. https://doi.org/10.5944/comunitania.2.3

Cantó,O. (2000). Income mobility in Spain: How much is there?. Review of Income and Wealth, 46(1), 85-102. https://doi.org/10.1111/j.1475-4991.2000. tb00392.x

Cantó, O., Gradín, C., \& Del Rio, C. (2012). Pobreza crónica, transitoria y recurrente en España. Revista de Economía Aplicada, 20(58), 69-94.

Castel, R. (2014). Los riesgos de exclusión social en un contexto de incertidumbre. Revista Internacional de Sociología, 72(E1), 15-24. https://doi. org/10.3989/ris.2013.03.18

Chant, S. (2006). Re-thinking the "Feminization of Poverty" in relation to aggregate gender indices. Journal of Human Development, 7(2), 201-220. https://doi. org/10.1080/14649880600768538 
Chen, K.-M., \& Wang, T.-M. (2015). Determinants of poverty status in Taiwan: A multilevel approach. Social Indicators Research, 123(2), 371389. https://doi.org/10.1007/s11205-014-0741-4

Dafermos, Y., \& Papatheodorou, C. (2013). What drives inequality and poverty in the EU? Exploring the impact of macroeconomic and institutional factors. International Review of Applied Economics, 27(1), 1-22. https://doi.org/10.1080/0 2692171.2012.696590

Dartanto, T. \& Nurkholis. (2013). The determinants of poverty dynamics in Indonesia: Evidence from panel data. Bulletin of Indonesian Economic Studies, 49(1), 61-84. https://doi.org/10.1080/00 074918.2013.772939

European Antipoverty Network - EAPN. (2014). Dossier Pobreza de EAPN ESPAÑA. 10 años de renovación de nuestro compromiso 20042014. Available at http://ibdigital.uib.es/greenstone/collect/portal_social/archives/eapn0017. dir/eapn0017.pdf

European Antipoverty Network - EAPN. (2015). El Estado de la Pobreza. $5^{\circ}$ Informe. Seguimiento del indicador de riesgo de pobreza y exclusión social en España 2009-2014. Red Europea de lucha contra la pobreza y la exclusión social. Available at http://eapn.es/ARCHIVO/documentos/recursos/1/1444833751_20151015_ el_estado_de_la_pobreza_seguimiento_del_ arope_2014_pdf.pdf

European Commission. (2010). Europe 2020: a strategy for smart, sustainable and inclusive growth. COM (2010) 2020. https://eur-lex.europa.eu/legal-content/en/ALL/?uri=CELEX\%3A52010DC2020

Eurostat. (2016a). Statistics explained: Europe in figures - Eurostat yearbook. Available at http:// ec.europa.eu/eurostat/statistics-explained/index. php/Europe_in_figures_-_Eurostat_yearbook

Eusrostat. (2016b). Statistics explained: People at risk of poverty or social exclusion. Available at http://ec.europa.eu/eurostat/statistics-explained/ index.php/People_at_risk_of_poverty_or_social_exclusion\#Source_data_for_tables_and_ figures_.28MS_Excel

Eurostat. (2016c). Statistics explained: Income distribution statistics. Available at http://ec.europa.eu/eurostat/statistics-explained/index.php/ Income_distribution_statistics/es

Eurostat. (2018). Glossary: At risk of poverty or social exclusion (AROPE). Available at https:// ec.europa.eu/eurostat/statistics-explained/index. php/Glossary:At_risk_of_poverty_or_social_exclusion_(AROPE)
Faura-Martínez, Ú., Lafuente-Lechuga, M., \& García-Luque, O. (2016). Risk of poverty or social exclusion: Evolution during the economic crisis and territorial perspective. Revista Española de Investigaciones Sociológicas, (156), 59-76. https://doi.org/10.5477/cis/reis.156.59

Fundación FOESSA. (2014). VII Informe sobre exclusión social y desarrollo social en España. Madrid: Cáritas-Fundación FOESSA.

García-Carro, B., \& Sánchez-Sellero, M. C. (2019). Medición de la pobreza subjetiva en España y su localización espacial. Revista Española de Investigaciones Sociológicas, (165), 83-100. https:// doi.org/10.5477/cis/reis.165.83

Gerovska-Mitev, M. (2015). Poverty and social exclusion in Macedonia, Serbia and Croatia: Status and policy responses. Revija za socijalnu politiku, 22(1), 81-94. https://doi.org/10.3935/ rsp.v22i1.1217

Herman, E. (2014). Working poverty in the European Union and its main determinants: An empirical analysis. Engineering Economics, 25(4), 427-436. https://doi.org/10.5755/j01.ee.25.4.6339

Herrero, C., Soler, A., \& Villar, A. (2013). Desarrollo y Pobreza en España y sus Comunidades Autónomas: El impacto de la crisis. Papeles de Economía Española, (138), 98-113.

Hooijer, G., \& Picot, G. (2015). European welfare states and migrant poverty: The institutional determinants of disadvantage. Comparative Political Studies, 48(14), 1-26. https://doi. org/10.1177/0010414015597508

Instituto Nacional de Estadística. (2006). La pobreza y su medición. Presentación de diversos métodos de obtención de medidas de pobreza.

Instituto Nacional de Estadística. (2016). Encuesta de Condiciones de Vida (ECV). Año 2015.

Instituto Nacional de Estadística. (2018). Encuesta de Condiciones de Vida (ECV). Año 2017.

Kwadzo, M. (2015). Choosing concepts and measurements of poverty: A comparison of three major poverty approaches. Journal of Poverty, 19(4), 409-423. https://doi.org/10.1080/10875549.201 5.1015067

Laparra, M., \& Pérez, B. (2012). Crisis y fractura social en Europa. Causas y efectos en España. Colección Estudios Sociales, 35. Barcelona: Obra Social «la Caixa».

Lekobane, K. R., \& Seleka, T. B. (2016). Determinants of household welfare and poverty in Botswana, 2002/2003 and 2009/2010. Journal of Poverty, 21(1), 1-19. https://doi.org/10.1080/10875549.2 016.1141381 
Maestro, I., \& Martínez, J. (2003). La pobreza humana y su feminización en España y las Comunidades Autónomas. Revista Española de Investigaciones Sociológicas, (104), 57-90. https://doi. org/10.2307/40184569

Mberu, B. U., Ciera, J. M., Elungata, P., \& Ezeh, A. C. (2014). Patterns and determinants of poverty transitions among poor urban households in Nairobi, Kenya. African Development Review, 26(1), 172-185.https://doi.org/10.1111/1467-8268.12073

Michálek, A., \& Výbošt'ok, J. (2019). Economic growth, inequality and poverty in the EU. Social Indicators Research, 141(2), 611-630. https://doi. org/10.1007/s11205-018-1858-7

Oliveri, M. N. (2013). Feminización de la pobreza en España: un análisis del estado de la cuestión [Feminization of poverty in Spain: a state-of- the-art review]. MPRA No. 47892. University Library of Munich, Germany.

Pagliacci, F. (2017). Regional paths towards Europe 2020 targets: a spatial approach. European Planning Studies, 25(4), 601-619. https://doi.org/10.1 080/09654313.2017.1280002

Pérez, A. J. (2013). Crisis económica y territorio: el impacto de la crisis sobre la desigualdad de rentas en las distintas regiones españolas. Papeles de Economía Española, (135), 36-49.

Sekhampu, T. J. (2013). Determinants of poverty in a South African township. Journal of Social Sciences, 34(2), 145-153. https://doi.org/10.1080 /09718923.2013.11893126

Zarzosa, P. (2002). Feminización de la pobreza en España?. Presentado en VIII Congreso de Economía Crítica, Valladolid (España). 
Sažetak

\title{
KOJE SKUPINE IMAJU VEĆI RIZIK SIROMAŠTVA U ŠPANJOLSKOJ?
}

\author{
Maria Carmen Sánchez-Sellero, Beatriz Garcia-Carro \\ Facultad de Economía y Empresa, Economía Aplicada \\ Universidade da Coruña \\ Coruña, Spain
}

Ekonomsku krizu koja je prisutna u Španjolskoj od 2008. godine pratilo je povećanje nejednakosti $i$ stope siromaštva. Cilj rada je odrediti najranjivije društvene skupine u smislu siromaštva u Španjolskoj. Empirijska analiza koristi informacije iz Ankete o uvjetima života iz 2015. godine, kako bi objasnila varijablu siromaštva koja je katalogizirana u tri kategorije (teško siromaštvo, umjereno siromaštvo i bez rizika od siromaštva) kod osoba starijih od 16 godina; eksplanatorne varijable su sociodemografske i radne, te predstavljaju različite skupine španjolskog stanovništva. Studija primjenjuje multinomični logistički regresijski model na posljednje podatke Ankete o životnim uvjetima, koji će nam omogućiti procjenu vjerojatnosti da je osoba starija od od 16 godina u stanju umjerenog siromaštva, teškog siromaštva ili je bez rizika od siromaštva za različite analizirane kategorije. Postoji nekoliko razlika u siromaštvu ovisno o spolu; kategorije koje najviše pogađa umjereno i I ili teško siromaštvo su razdvojene i razvedene osobe, stranci koji nisu iz Europske unije, osobe s niskom razinom obrazovanja i privremenim zaposlenjem. Moramo prihvatiti da u situacijama poteškoća postoje neke skupine koje su zbog svojih gospodarskih uvjeta u lošijem položaju za suočavanje s nepovoljnim situacijama.

Ključne riječi: ekvivalentni dohodak, rad, logit, stope siromaštva, sociodemografska obilježja, pragovi siromaštva. 